\title{
Multicoloured lenticular opacities in a case of cerulean cataract
}

\author{
Devesh Kumawat, ${ }^{\ominus}$ Navarosh Jayaraman, Pranita Sahay, Parijat Chandra
}

Dr. Rajendra Prasad Centre for Ophthalmic Sciences, All India Institute of Medical Sciences, New Delhi, India

\section{Correspondence to} Dr Parijat Chandra, parijatchandra@gmail.com

Accepted 21 April 2019

\section{DESCRIPTION}

A 13-year-old girl presented with a 4-month history of diminution of vision in both eyes. The best corrected distance visual acuity was 20/30 OU. Diffuse light examination on slit lamp revealed bluish white tiny opacities throughout the lens forming concentric layers in both eyes (figure 1A). Detailed slit examination highlighted opacities of various colours: white, blue, greenish-blue, grey and red (figure 1B). The posterior segment was unremarkable in both eyes. Her brother also had similar lenticular opacities suggestive of cerulean cataract. Though the child did not complain of other visual disturbances, glare and contrast sensitivity might also be tested. A regular follow-up was advised.

Cerulean or blue-dot cataracts are autosomal dominant early onset bilateral cataracts with concentric layers of bluish-white opacities which may form large cuneiform shapes in the mid-periphery. ${ }^{1-5}$ These appear from birth to early childhood but may not be diagnosed until adulthood. It may be caused by mutations in certain genes: crystallin $\beta$-B2 (CRYBB2), crystallin $\gamma$-D (CRYGD), musculoaponeurotic fibrosarcoma and major intrinsic protein genes. ${ }^{1-3}$ The mutations in these genes are responsible for early onset pulverulent cataract and cerulean cataract. ${ }^{3}$

The progression of cataract is slow and may not become visually significant till the third to fourth decades when surgery may be helpful. ${ }^{45}$ Initially the opacities appear at the edge of the fetal lens nucleus. With time the opacities involve the adult

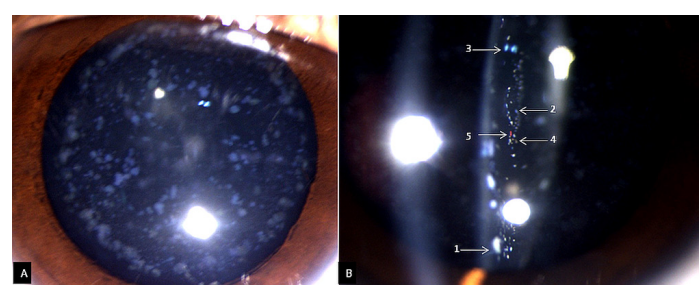

Figure 1 (A) Diffuse light slit lamp photograph of the right eye shows bluish-white opacities throughout the lens forming concentric layers. (B) Slit examination of the same eye with multicoloured opacities marked with numbers: white (1), blue (2), greenish-blue (3), grey (4) and red (5). nucleus and the cortex in the form of concentric circles. The central lesions are arranged radially. They may also have associated central sutural cataract. ${ }^{5}$ The multicoloured cortical opacities were perhaps dense and present in the visual axis in the present case and may be the reason for the slight visual disturbance. Patients with cerulean cataract do not have any associated systemic comorbidities and need not be evaluated.

\section{Learning points}

- Cerulean or blue-dot cataract is an early onset familial cataract with predominant bluish-white lenticular opacities.

- Although cerulean cataract may be observed in childhood, it is usually visually insignificant.

- The visual acuity usually gets affected in adulthood, when cataract extraction may be needed.

Contributors DK: acquisition of data, analysis and interpretation of data, drafting the article. NJ: acquisition of data, drafting the article. PS: acquisition of data, revising the article critically for important intellectual content. PC: conception and design, revising the article critically for important intellectual content. All authors: final approval of the version published, agreement to be accountable for the article and to ensure that all questions regarding the accuracy or integrity of the article are investigated and resolved.

Funding The authors have not declared a specific grant for this research from any funding agency in the public, commercial or not-for-profit sectors.

\section{Competing interests None declared.}

Patient consent for publication Parental/guardian consent obtained.

Provenance and peer review Not commissioned; externally peer reviewed.

\section{REFERENCES}

1 Litt M, Carrero-Valenzuela R, LaMorticella DM, et al. Autosomal dominant cerulean cataract is associated with a chain termination mutation in the human beta-crystallin gene CRYBB2. Hum Mol Genet 1997:6:665-8.

2 Armitage MM, Kivlin JD, Ferrell RE. A progressive early onset cataract gene maps to human chromosome 17q24. Nat Genet 1995;9:37-40.

3 Xiao X, Li W, Wang P, et al. Cerulean cataract mapped to 12q13 and associated with a novel initiation codon mutation in MIP. Mol Vis 2011;17:2049-55.

4 Provencher LM, Critser B, Johnson AT. Cerulean cataract. JAMA Ophthalmol 2018;136:e183150.

5 Ram J, Singh A. Cerulean cataract. QJM 2019;37. 
Images in...

Copyright 2019 BMJ Publishing Group. All rights reserved. For permission to reuse any of this content visit https://www.bmj.com/company/products-services/rights-and-licensing/permissions/

BMJ Case Report Fellows may re-use this article for personal use and teaching without any further permission.

Become a Fellow of BMJ Case Reports today and you can:

- Submit as many cases as you like

- Enjoy fast sympathetic peer review and rapid publication of accepted articles

Access all the published articles

- Re-use any of the published material for personal use and teaching without further permission

For information on Institutional Fellowships contact consortiasales@bmjgroup.com

Visit casereports.bmj.com for more articles like this and to become a Fellow 